\title{
TARIF VOLUME LOKAL POHON JATI (Tectona grandis) DI HUTAN KEMASYARAKATAN SEDYO RUKUN KABUPATEN GUNUNGKIDUL
}

\section{(THE LOCAL VOLUME RATE OF TEAK TREE (Tectona Grandis) IN SEDYO RUKUN COMMUNITYFOREST GUNUNGKIDUL REGENCY)}

\author{
Oleh \\ Dhea Lupita Dinda Wijaya ${ }^{1^{*}}$, Rochmad Hidayat ${ }^{2)}$, Probo Santoso ${ }^{3)}$ \\ ${ }^{1,2,3)}$ Program Studi Pengelolaan Hutan, Departemen THV, Sekolah Vokasi, Universitas Gadjah Mada, Sekip Unit \\ II, Yogyakarta, 55281; Telp (0274) 551752 \\ Email: Dhealupitadindawijaya@gmail.com \\ \begin{tabular}{l|l} 
Diterima 6 Februari 2021 & Disetujui: 30 Maret 2021
\end{tabular}
}

\begin{abstract}
Abstrak
Kegiatan pengelolaan hutan Jati pada HKm di Gunung Kidul menjadi salah satu sumber penghasil kayu. Namun demikian alat penaksir volume kayu perencanaan produksi belum tersedia. Oleh karena itu diperlukan penyusunan alat penaksir volume kayu tersebut dalam rangka memudahkan kegiatan perencanaan produksi. Tujuan dari penelitian ini adalah membuat persamaan regresi hubungan antara keliling dengan volume dan menyusun tarif volume lokal (TVL) pohon Jati (Tectona grandis) pada area Hutan Kemasyarakatan (Hkm) Sedyo Rukun, Desa Banyusoco, Playen, Gunung Kidul, Daerah Istimewa Yogyakarta. Teknik sampel yang digunakan adalah purposive sampling dengan sampel berupa volume pohon hasil tebangan. Volume pohon dihitung dengan rumus smalian. TVL disusun dengan tahapan, uji normalitas data, penyusunan model persamaan regresi, dan uji validasi. Pemilihan model terbaik mempertimbangkan kriteria nilai (koefisien determinasi) $\mathrm{R}^{2}$, (kesalahan standar estimasi) Se, Uji F, chi-square ( $\left.\mathrm{x}^{2}\right)$, SA, SR, bias dan RMSE. Berdasarkan hasil penelitian, model regresi terbaik terbaik adalah model power dengan rumus $\mathrm{V}=$ dengan nilai $\mathrm{R}^{2}$ 0,865; Se 0,390; SA -2,97; SR 0,16\%; Bias 1,76 $\%$; RMSE 2,68\% dan chi-square 3,03.
\end{abstract}

Kata kunci: Jati, HKm, Analisis regresi, Tarif Volume Lokal, Perencanaan hutan.

Abstract

The activity of Teak (Tectona grandis) forest management on $\mathrm{HKm}$ in Gunungkidul is one of the wood production sources. However, the wood volume estimator for production planning is unavailable yet. Therefore, it is necessary to prepare a wood volume estimator to facilitate production planning. The goal of this research is to create a regression equation for the relationship between circumference and volume and compiling the local volume rate (TVL) of Teak trees (Tectona grandis) in the Sedyo Rukun Community Forest (Hkm) area, Banyusoco Village, Playen, Gunungkidul, Special Region of Yogyakarta. The sampling technique that used was purposive sampling with the sample was in the form of felled trees volume. The volume of the tree was calculated by using the smalian's formula. TVL was arranged in some stages, data normality test, regression equation model, and validation test. The selection of the best model is considering into the criteria value of (coefficient of determination) $\mathrm{R}^{2}$, (standard error of estimation) Se, F test, chi-square ( $\left.\mathrm{x}^{2}\right)$, SA, SR, bias, and RMSE. Based on the research results, the best regression model is the power model with the formula $\mathrm{V}=$ with the value of $\mathrm{R}^{2}$ is 0.865 ; SE 0,390; SA -2.97; SR 0.16\%; Bias 1.76\%; RMSE 2.68\% and chi-square 3,03.

Keyword: Jati, HKm, Regression analysis, Local Volume Rate, Forest Planning. 


\section{PENDAHULUAN}

Kegiatan pengelolaan hutan memerlukan informasi penting dalam rangka kegiatan penyusunan tata kelola hutan yang memiliki tujuan untuk menghasilkan kayu secara lestari terutama mengenai potensi massa (volume) tegakan. Sehingga perlu adanya suatu alat untuk menyajikan dugaan volume kayu di suatu areal hutan yang dikelola ke dalam bentuk tabel volume Wayan (2017), menyatakan dalam menghitung volume batang yang berukuran relatif pendek akan menghasilkan kecermatan yang lebih baik, sehingga penyusunan tabel dilakukan dengan pembagian batang yang relatif lebih pendek, yang kemudian dapat disajikan dengan tabel volume.

Tabel volume pohon lokal (TVL) merupakan bentuk khusus dari tabel volume pohon. Tabel volume pohon lokal memberikan nilai volume pohon hanya dengan mengetahui satu variabel saja dari pohon yang bersangkutan, variabel tersebut yaitu keliling pohon. Tabel volume pohon merupakan hasil dari kegiatan pendugaan volume dengan menggunakan hubungan antara volume dan dbh atau keliling. Oleh sebab itu, pendugaan tabel atau tarif volume pohon ini dilakukan dengan menghitung per-seksi atau tiap sortimen dari batang tersebut guna menghasilkan volume yang memiliki

\section{METODE PENELITIAN}

Penelitian ini dilakukan di Petak 95, Areal Hutan Kemasyarakatan (Hkm) Sedyo Rukun, RPH Menggoro,BDH Paliyan, Desa tingkat ketelitian tinggi. Penyusunan tabel volume pohon digunakan sebagai alat bantu dalam kegiatan inventarisasi hutan digunakan untuk pendugaan volume dari suatu pohon berdiri dalam areal tegakan, kemudian selanjutnya untuk menduga persediaan kayu dalam tegakan (standing stock). Tersedianya tabel volume pohon ini akan mempermudah kegiatan suatu kegiatan pengelolaan hutan terutama pada hutan dengan jumlah tegakan yang banyak dan memiliki area yang luas.

Penaksiran volume kayu di suatu areal hutan dapat dilakukan dengan cara pengukuranpengukuran secara langsung di lapangan dimana pohon-pohon yang dipilih mampu mewakili seluruh tegakan dalam areal hutan tersebut. Penaksiran volume juga dapat dilakukan secara tidak langsung dengan menggunakan Tabel Volume Lokal (TVL). Volume tegakan dapat dinyatakan dengan karakteristik-karakteristik pohon seperti luas bidang dasar dan tinggi pohon rata-rata. Perlunya alat penduga volume melatar belakangi penelitian ini untuk dilakukan tujuannya agar masyarakat khususnya petani hutan atau pemilik lahan di hutan kemasyarakatan (HKm) Gunungkidul bisa mengetahui volume pohon hasil pemanenan pohon Jati yang telah dilakukan.

Banyusoco,Kecamatan Playen, Kabupaten Gunungkidul, Daerah Istimewa Yogyakarta. Pengumpulan data dilakukan selama satu bulan. Alat yang digunakan dalam penelitian ini adalah 
Tallysheet, GPS Garmin 78s, Phiband, Hagameter, roll meter dan pita ukur. Pengukuran pohon sampel dilakukan dengan cara mengukur keliling pohon yang akan ditebang dengan menggunakan phiband setinggi 1,3 meter dari permukaan tanah atau pada setinggi dada, kemudian menunggu pohon tersebut ditebang. Setiap pohon yang telah ditebang dibagi menjadi beberapa seksi atau sortimen dengan diukur menggunakan meteran

Hasil pengukuran jumlah dan panjang sortimen masing-masing pohon dicatat pada tallysheet yang sudah disediakan. Setelah data hasil pengukuran telah diambil, kemudian menghitung volume pohon dengan menjumlahkan volume tiap sortimen. Analisis data menggunakan Uji Normalitas dengan metode Kolmogorov Smirnovtest. Dahlan (2009), uji Kolmogorov-Smirnovtes lebih tepat Pengukuran volume pohon dari data hasil uji normalitas dihitung setiap seksi dengan menggunakan rumus Volume Smalian. Adapun bentuk rumus dari volume smalian (Prodan, 1965):

$\mathrm{Vs}=1 / 4 \pi \frac{(d u)^{2}+(d p)^{2}}{2} \times \mathrm{L}$, dimana Vs = volume Smalian (volume per seksi batang), du = luas bidang dasar ujung $(\mathrm{cm}), \mathrm{dp}=$ luas bidang dasar pangkal $(\mathrm{cm})$, dan $\mathrm{L}=$ panjang seksi/sortimen.

Analisis selanjutnya adalah menyusun model penggunaan volume dengan menggunakan persamaan regresi dengan software SPSS. Ada beberapa model yang memiliki panjang setiap seksi adalah tiga meter pada pangkal batang atau awal seksi, dan sebesar dua meter pada seksi setelahnya. Bagian cabang atau ranting pohon yang memiliki diameter lebih dari sama dengan $3 \mathrm{~cm}$ dengan panjang lebih dari sama dengan $0,40 \mathrm{~m}$ (SNI 01-5007.17-2001 dan SNI 01-5007.1-2003) dibuang yang kemudian akan dikumpulkan oleh masyarakat untuk keperluan kayu bakar.

untuk sampel yang lebih dari 50. Pengujian ini dilakukan dengan membandingkan distribusi kumulatif dari data yang telah disediakan dengan distribusi normal yang diharapkan dengan menunjukkan hasil nilai signifikasi $(\mathrm{p}>0,05)$ yang berarti tidak ada perbedaan antar kedua distribusi tersebut (Wahyu, 2012) atau dapat ditunjukkan dengan histogram yang berbentuk hampir menyerupai lonceng.

penyusunan pendugaan volume pohon menurut Lukito (2010): 
Tabel 1. Model Persamaan Regresi dan Transformasinya

\begin{tabular}{lll}
\hline Bentuk & Persamaan & Bentuk Linier \\
\hline Linier & $\mathrm{Y}=\mathrm{a}+\mathrm{bx}$ & $\mathrm{Y}=(1 / \mathrm{u}+\mathrm{abx})-1$ \\
\hline Kuadratic & $\mathrm{Y}=\mathrm{a}+\mathrm{bx}+\mathrm{cx} 2$ & $\mathrm{Y}=\mathrm{a}+\mathrm{bx}+\mathrm{cx} 2$ \\
\hline Kubik & $\mathrm{Y}=\mathrm{a}+\mathrm{bx}+\mathrm{cx} 2+\mathrm{dx} 3$ & $\mathrm{Y}=\mathrm{a}+\mathrm{bx}+\mathrm{cx} 2+\mathrm{dx} 3$ \\
\hline Logaritma & $\mathrm{Y}=\mathrm{a}+\mathrm{b}$ In $\mathrm{x}$ & $\mathrm{Y}=\mathrm{a}+\mathrm{bx}+\mathrm{cx} 2+\mathrm{dx} 3$ \\
\hline Inverse & $\mathrm{Y}=\mathrm{a}+\mathrm{b} / \mathrm{x}$ & $\mathrm{Y}=\mathrm{a}+\mathrm{b} / \mathrm{x}$ \\
\hline Compound & $\mathrm{Y}=\mathrm{abx}$ In & $\mathrm{Y}=\mathrm{In} \mathrm{a}+\mathrm{x}$ In $\mathrm{b}$ \\
\hline Power & $\mathrm{Y}=\mathrm{axb}$ In & $\mathrm{Y}=\mathrm{In} \mathrm{a}+\mathrm{b}$ In $\mathrm{x}$ \\
\hline Sigmoid & $\mathrm{Y}=\mathrm{ea}+\mathrm{b} / \mathrm{t}$ In & $\mathrm{Y}=\mathrm{a}+\mathrm{b} / \mathrm{t}$ \\
\hline Growth & $\mathrm{Y}=\mathrm{ea}+\mathrm{bx}$ In & $\mathrm{Y}=\mathrm{a}+\mathrm{bx}$ \\
\hline Ekponensial & $\mathrm{Y}=\mathrm{a}(\mathrm{ebx}) \mathrm{In}$ & $\mathrm{Y}=\mathrm{In} \mathrm{a}+\mathrm{bx}$ \\
\hline Logistik & $\mathrm{Y}=(1 / \mathrm{u}+\mathrm{abx})-1$ & $\mathrm{In}(1 / \mathrm{Y}-1 / \mathrm{u})=\operatorname{In} \mathrm{a}+\mathrm{x}$ In $\mathrm{b}$ \\
\hline
\end{tabular}

Pemilihan persamaan/model yang paling baik dilakukan dengan melihat nilai koefisien korelasi (r) dan koefisien determinasi $\left(\mathrm{R}^{2}\right)$ tertinggi, uji $\mathrm{F}$, serta nilai standar error (SE) terkecil. Nilai koefisien determinasi berkisar antara 0 sampai 1 , sedangkan nilai kofisien korelasi berkisar dari -1 sampai +1 . Apabila menggunakan perhitungan Selanjutnya adalah uji validasi, jika sebuah model persamaan telah memenuhi kriteria yang telah diterapkan dalam penyusunan model dan dapat dikatakan bahwa dapat diterima sebagai model peramalan yang bermanfaat (Fredy dan Relawan, 2019). Uji validasi dapat dilakukan dengan menggunakan uji $x^{2}$ (chisquare), SA (Simpangan Agregat), SR (Simpangan Rata-rata), RMSE (Root Mean Square Error), dan nilai Bias (e). Pengujian validasi model dengan uji $x^{2}$ (chi-square) yaitu untuk mengetahui apakah volume yang diduga (Vd) akan berbeda dengan volume pohon aktual (Va). Hipotesa yang diuji sebagai berikut

$$
\mathrm{RMSE}=\sqrt{\frac{\sum\left(\frac{V d-V a}{V a}\right)^{2}}{n}} \times 100
$$

manual, koefisien determinasi dihitung berdasarkan rumus sebagai berikut: $\mathrm{R}^{2}=$ JKR/JKT, dimana $\mathrm{R}^{2}=$ Koefisien Determinasi, JKR = Jumlah Kuadrat Rataan, JKT $=$ Jumlah Kuadrat Tengah, dan Nilai koefisien korelasi (r) dihitung berdasarkan rumus berikut: $\mathrm{r}=\sqrt{R^{2}}$.

(Simon, 2007): X2 hitung: $=\sum \frac{(V d-V a)^{2}}{\mathrm{Vd}}$, kaidah keputusannya adalah: $x^{2}$ hitung $=x^{2}$ tabel , maka Ho diterima, jika $x^{2}$ hitung $>x^{2}$ tabel, maka Ho ditolak. Nilai bias dapat dihitung dengan menggunakan rumus: $\mathrm{B}=$ $\left|\sum\left\{\frac{\frac{V d i-V a i}{V a i}}{n}\right\}\right| x 100 \%, \quad$ dimana $\quad$ Vdi adalah volume dugaan ke-i yang didapat dari hasil persamaan dan Vai adalah volume aktual yang diperoleh dari penjumalahan seksi pohon ke-i. Penghitungan nilai RMSE, SA, dan SR dapat diitung dengan menggunakan rumus (Bustomi et al,1998): 


$$
\begin{aligned}
& \mathrm{SA}=\left(\frac{\sum V d-\sum V a}{\sum V d}\right) \\
& \mathrm{SR}=\frac{\sum\left(\frac{V d-V a}{V d}\right)^{1}}{n} \times 100,
\end{aligned}
$$

dimana

Vd adalah volume persamaan/ volume dugaan dan

$\mathrm{Va}$ adalah volume aktual, $\mathrm{n}$ adalah jumlah pohon.

SR, RMSE, bias, chi-square dan uji-F terendah

Langkah selanjutnya yaitu pemilihan model terbaik didasarkan pada sistem skoring pada proses penyusunan model dan tahap validasi. Sistem skoring berdasar pada nilai koefisien determinasi, SA, SR, RMSE, bias, chisquare, dan uji-F. Model terbaik adalah moodel yang memiliki skor terendah (Kuswandi, 2016). Siagian (2011), juga menyebutkan pemelihan model dilakukan dengan melakukan pemeringkatan terhadap skor pada tahap penyusunan persamaan dan validasi model. Nilai 1 diberikan kepada model dengan melakukan sistem skoring terhadap nilai SA, SR, RMSE, bias, chi-square, dan uji-F terendah dan terhadap nilai koefisien determinasi tertinggi. Nilai 2 diberikan kepada model dengan nilai SA,

\section{HASIL DAN PEMBAHASAN}

Data hasil pengukuran pohon di lapangan selanjutnya digunakan untuk mencari normalitas data terhadap seluruh sampel pohon. Uji normalitas merupakan uji yang melaporkan hasil atau nilai signifikansi (p). Nilai p menunjukkan bahwa seberapa jauh kemungkinan sebuah data yang telah diolah menyimpang dari distribusi normal yang ideal (Wahyu, 2012). kedua dan terhadap nilai koefisien determinasi tertinggi kedua. Nilai selanjutnya diberikan dengan menggunakan sistem yang sama pada persamaan yang telah dibuat (Freddy dan Relawan, 2019). Menurut Sumadi et al (2010), pemilihan model terbaik perlu dilakukan berdasarkan sistem skoring terhadap kriteria statistik karena model tertentu bisa memiliki nilai yang lebih tinggi pada suatu kriteria namun rendah pada kriteria statistiknya. Model terpilih akan menjadi model penduga volume pohon jenis Jati (Tectona grandis L.f) di areal $\mathrm{HKm}$ Sedyo Rukun, RPH Menggoro, BDH Paliyan, Desa Banyusoco, Kecamatan Playen, Kabupaten Gunung Kidul, Daerah Istimewa Yogyakarta.

Sebanyak 39 pohon yang digunakan dalam penyusunan persamaan pendugaan volume dan sisanya sebanyak 18 pohon digunakan sebagai uji validasi. Menurut Amri R (2011), untuk pengujian validasi ini diperlukan sepertiga dari jumlah pohon sampel yang tidak digunakan dalam penyusunan model-model penduga volume. 


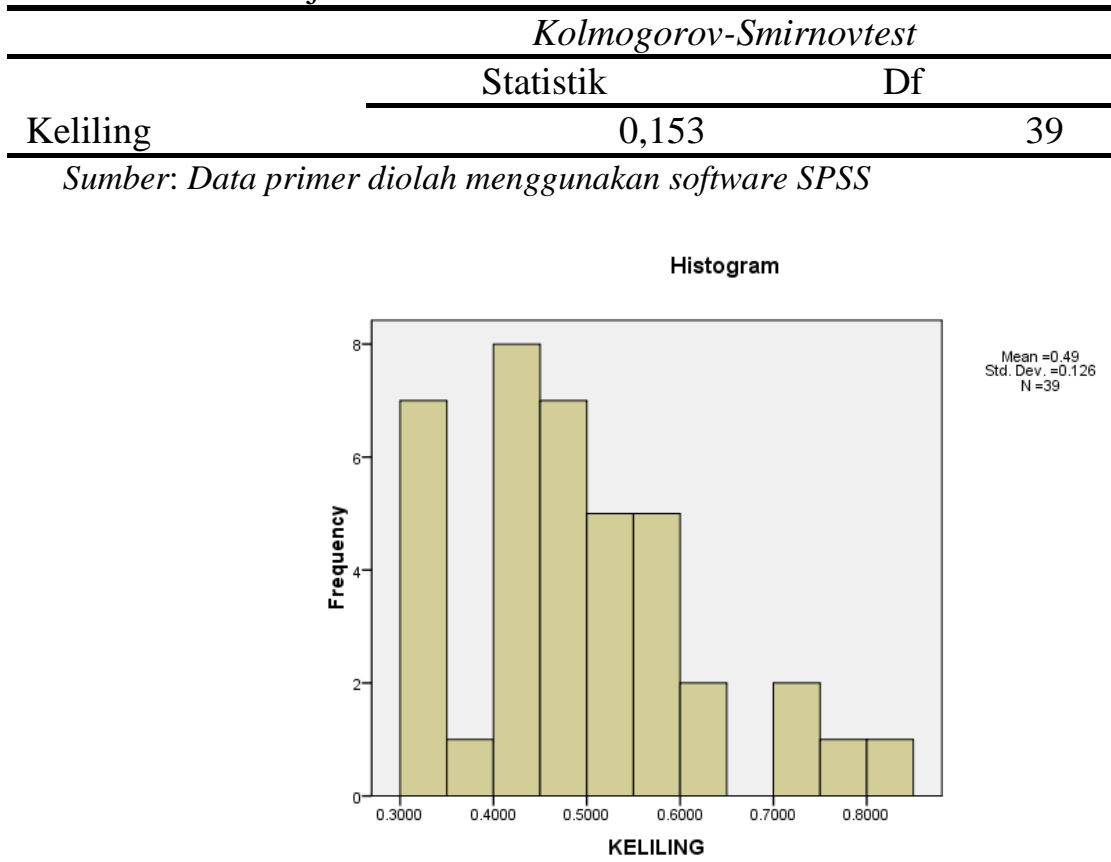

Gambar 1. Diagram Frekuensi Keliliang Pohon Hasil Uji Normalitas

Hasil yang didapatkan dari uji Kolmogorov-Smirnovtest dapat digunakan pada Kolmogorov-Smirnovtest menunjukkan nilai data yang memiliki sampel kecil maupun besar, signifikansi $(p)>0,05$ yaitu senilai 0,22 . Hal ini oleh karena itu penggunaan uji Kolmogorovdapat dikatakan data telah terdistribusi normal Smirnovtest memiliki tingkat konsistensi yang dengan jumlah pohon menjadi 39 pohon. sama baik pada sampel 50 maupun kurang dari Cahyono (2006) menyebutkan bahwa uji 50.

Tabel 3. Distribusi Frekuensi Data Hasil Uji Normalitas

\begin{tabular}{|l|l|l|l|l|}
\hline $\begin{array}{c}\text { Kelas Keliling } \\
(\mathrm{m})\end{array}$ & \multicolumn{1}{|c|}{$\sum$ Pohon } & $\begin{array}{c}\text { Rerata } \\
\text { sortimen }\end{array}$ & $\begin{array}{c}\text { Rerata Panjang } \\
(\mathrm{cm})\end{array}$ & \multicolumn{1}{|c|}{$\begin{array}{c}\text { Rerata Volume } \\
\left(\mathrm{m}^{3}\right)\end{array}$} \\
\hline $0.31-0.39$ & 8 & 2 & 3,25 & 0.09 \\
\hline $0.4-0.47$ & 14 & 2 & 2,45 & 0.05 \\
\hline $0.48-0.55$ & 6 & 3 & 2,62 & 0.14 \\
\hline $0.56-0.63$ & 7 & 3 & 3 & 0.19 \\
\hline $0.64-0.71$ & 0 & 0 & 0 & 0 \\
\hline $0.72-0.79$ & 3 & 3 & 2,88 & 0,31 \\
\hline $0.8-0.87$ & 1 & 5 & 2,6 & 0,5 \\
\hline
\end{tabular}

Sumber: Data Primer

Sebaran pohon terbanyak pada hasil uji normalitas terdapat pada kelas keliling $0.4-0.47$ meter atau memiliki diameter 13 - 15 sentimeter.
Seperti teori yang dikemukakan oleh Farida dkk (2016), keliling pohon pada HKm atau hutan produksi khususnya jenis jati memiliki variasi 
diameter atau keliling yang rendah dibandingakan dengan hutan alam seperti yang terlihat pada tabel distribusi frekuensi di atas.

Hal mendasar yang diperlukan dalam penyusunan model pendugaan volume pohon adalah apakah terdapat hubungan yang erat antara keliling pohon dan tinggi, maka penyusunan model pendugaan volume menggunakan persamaan yang memakai variabel diameter atau keliling saja (Farida dkk, 2016). Model-model regresi yang digunakan untuk pendugaan volume pohon jati yaitu model linear, eksponensial, logaritmik, kuadratik, dan power.
Model ini dipilih berdasarkan tingkat ketelitian,ketepatan dan kesederhanaan dari persamaan yang dihasilkan oleh masing-masing model.

Menurut Wayan (2017), kesalahan baku yang dianjurkan pada penyusunan model persamaan regresi yang menggunakan satu variabel adalah sebesar $25 \%$ dan $20 \%$ untuk persamaan yang menggunakan dua variabel. Bentuk persamaan model volume pohon disajikan dalam Tabel 4 sedangkan kurva hubungan regresi keliling dan volume pohon dapat dilihat pada Gambar 2 hingga Gambar 6.

Tabel 4. Bentuk persamaan berbagai model regresi

\begin{tabular}{lll}
\hline No & \multicolumn{1}{c}{ Model Persamaan } & Std. Error \\
\hline 1 & $\begin{array}{l}\text { Logaritmik } \square \mathrm{y}=\mathrm{a}+\mathrm{b} \text { In } \mathrm{x} \\
\mathrm{a}=1,115 \mathrm{~b}=0,351\end{array}$ & 0,091 \\
\hline 2 & $\begin{array}{l}\text { Kuadratik } \square \mathrm{y}=\mathrm{cx}^{2}-\mathrm{bx}+\mathrm{a} \\
\mathrm{a}=0,073 \mathrm{~b}=0,003 \mathrm{c}=0,001\end{array}$ & 0,087 \\
\hline 3 & $\begin{array}{l}\text { Power } \square \mathrm{y}=\mathrm{bx}^{\wedge} \mathrm{a} \\
\mathrm{a}=2,393 \mathrm{~b}=0,016\end{array}$ & 0,390 \\
\hline 4 & $\begin{array}{l}\text { Eksponensial } \square \mathrm{y}=\mathrm{a}(\mathrm{ebx}) \\
\mathrm{a}=0,013 \mathrm{~b}=0,045\end{array}$ & 0,397 \\
\hline 5 & $\begin{array}{l}\text { Linear } \square \mathrm{y}=\mathrm{bx}-\mathrm{a} \\
\mathrm{a}=0,218 \mathrm{~b}=0,007\end{array}$ & 0,088 \\
\hline
\end{tabular}

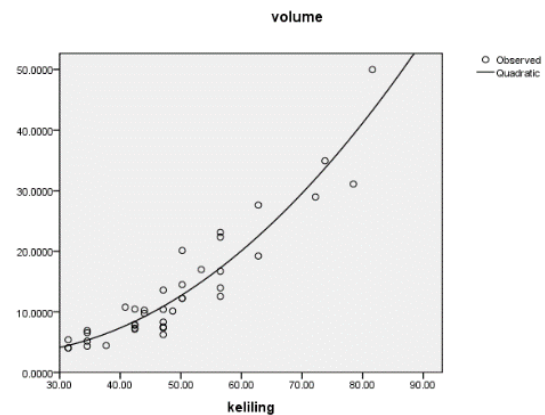

Gambar 2. Kurva regresi hubungan keliling dan volume pohon model kuadratik

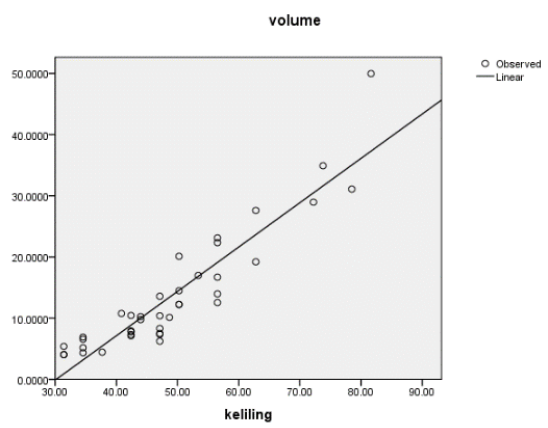

Gambar 3. Kurva regresi hubungan keliling dan volume pohon model linier

IGambar 4. Kurva regresi hubungan Gambar 5. Kurva regresi hubungan 


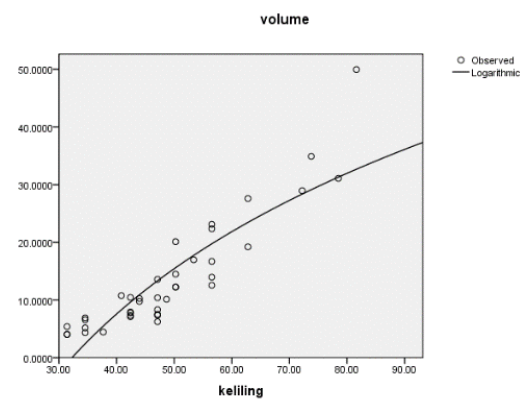

keliling dan volume pohon model logaritmik

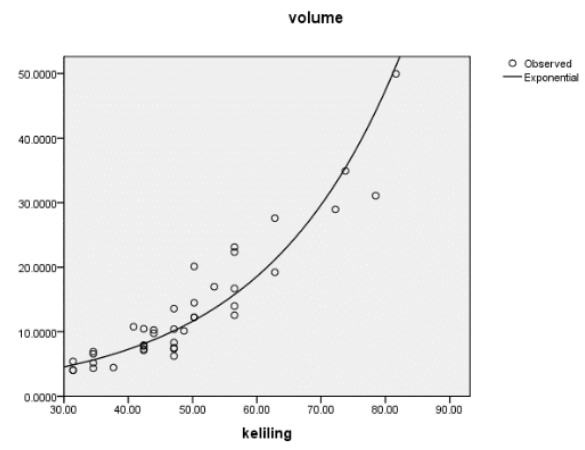

Gambar 6. Kurva regresi hubungan keliling dan volume pohon model eksponensial

Model logaritmik, kuadratik, dan linear mempunya nilai Se sesuai dengan persyaratan yang diperkenankan. Sementara untuk model persamaan power dan persamaan eksponensial memiliki nilai $\mathrm{Se}>25 \%$ sehingga kedua model tersebut tidak sesuai dengan syarat yang diperkenankan atau dapat dikatakan model ini bukan model persamaan untuk menduga volume pohon yang terbaik. Pada Gambar 2, 5, dan 6 menunjukkan kurva hubungan keliling (x) dan volume pohon (y) dari model persamaan kuadratik, power, dan eksponensial. Grafik Hal yang perlu diperhatikan saat pendugaan volume yaitu dengan melakukan uji $\mathrm{F}$ untuk mengetahui perananan variabel bebas

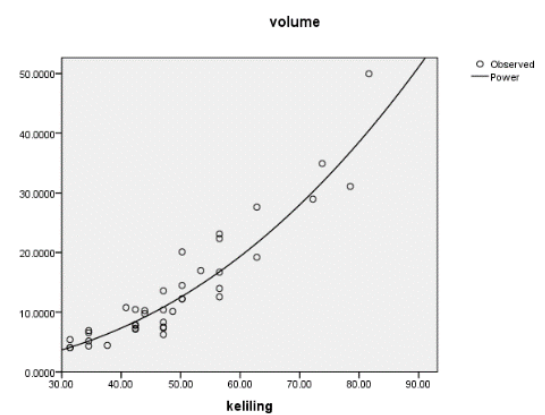

keliling dan volume pohon model power tersebut berbentuk lengkung hampir menyerupai $\mathrm{U}$ antara nilai keliling dan volume. Nilai x akan meningkat akan tetapi pada awalnya nilai y akan menurun. Namun apabila semakin meningkatnya nilai x maka nilai y akan ikut meningkat di atas nilai minimumnya. Sementara pada Gambar 3 menunjukkan hubungan garis lurus atau linear positif antara $\mathrm{x}$ dan $\mathrm{y}$, apabila $\mathrm{x}$ meningkat maka y akan meningkat pula. Gambar 4 yang menunjukkan kurva hubungan regresi pada model persamaan logaritmik yang digambarkan hubungan lengkung positif antara $\mathrm{x}$ dan $\mathrm{y}$. dalam menduga variabel tidak bebas yang disajikan pada tabel 6. Uji validasi model perlu untuk dilakukan karena uji ini bertujuan untuk 
melihat kevalidan suatu model yang telah dibuat dalam menduga volume pohon. Sugiyono (2011), hasil penelitian dikatakan valid apabila adanya kesamaan antara data asli pengukuran dilapangan dengan data hasil penelitian. Hasil persamaan regresi dan uji validasi seluruh model disajikan dalam tabel 5.

Tabel 5. Hasil Persamaan regresi dan uji validasi

\begin{tabular}{|c|c|c|c|c|c|c|c|c|c|c|}
\hline \multirow[b]{2}{*}{ No } & \multirow[b]{2}{*}{ Kode } & \multirow[b]{2}{*}{$\mathrm{R}$} & \multirow[b]{2}{*}{$\mathrm{R}^{2}$} & \multirow[b]{2}{*}{$\begin{array}{c}\mathrm{F} \\
\text { hitung }\end{array}$} & \multirow[b]{2}{*}{$\begin{array}{l}\underset{F}{F} \\
\text { tabel } \\
(0,05)\end{array}$} & \multicolumn{5}{|c|}{ Uji Validasi } \\
\hline & & & & & & SA & $\begin{array}{l}\text { SR } \\
(\%)\end{array}$ & $\begin{array}{l}\text { RMSE } \\
(\%)\end{array}$ & $\begin{array}{c}\text { Chi } \\
\text { Square } \\
\text { (chi } \\
\text { tabel } \\
27,58)\end{array}$ & $\begin{array}{l}\text { Bias } \\
(\%)\end{array}$ \\
\hline 1 & A1 & 0,669 & 0,769 & $\begin{array}{l}5307, \\
1\end{array}$ & 4,14 & 0,93 & 0,89 & 32,97 & 35,03 & 24,58 \\
\hline 2 & B1 & 0,714 & 0,891 & 84,62 & 4,14 & 0,87 & 0,86 & 15,45 & 16,73 & 12,48 \\
\hline 3 & $\mathrm{C} 1$ & 0,828 & 0,865 & 5,93 & 4,14 & 0,39 & 0,16 & 2,68 & 8,23 & 1,76 \\
\hline 4 & D1 & 0,821 & 0,861 & $\begin{array}{l}382,1 \\
3\end{array}$ & 4,14 & 0,85 & $\begin{array}{l}12,2 \\
3\end{array}$ & 16,26 & 14,02 & 11,8 \\
\hline 5 & E1 & 0,698 & 0,846 & 20,24 & 4,14 & $-4,24$ & 5,22 & 1,03 & 24,40 & 0,78 \\
\hline
\end{tabular}

Tabel di atas menunjukkan pada model persamaan kuadratik, power, dan eksponensial memiliki koefisien korelasi lebih dari 0,70 dan koefisien determinasi $>50 \%$. Menurut Suharlan et al (1976), nilai $\mathrm{R}^{2}$ sebesar 50\%, dianggap sebagai batas minimal yang dapat digunakan dalam penyusunan tabel volume dan sudah dapat digunakan. Sementara batas ketelitian untuk koefisien korelasinya sebesar $>0$,70. Namun, persamaan kuadratik memiliki nilai koefisien determinasi tertinggi yaitu $68,5 \%$. Nilai 0,891 pada koefisien determinasi menunjukkan bahwa a. 0,70 s.d.1,00 menunjukkan terdapatnya tingkat hubungan yang tinggi.

b. 0,40 s.d. $<0,7$ menunjukkan tingkat hubungan yang substansi.

Semua model memiliki nilai $\mathrm{F}$ hitung lebih besar daripada $\mathrm{F}$ tabel untuk tingkat signifikansi 5\%. Penggunaan tingkat signifikansi
$89,1 \%$ keragaman volume ditunjukkan oleh variabel bebas keliling sedangkan sisanya dijelaskan oleh variabel lain yang tidak disertakan pada model misalnya variabel tinggi.

Sementara nilai koefisien korelasi mempunya nilai $\mathrm{p}>0,70(0,828>0,70)$ pada tingkat nyata tertentu, sehingga koefisien korelasi antara tinggi dengan keliling telah memenuhi persyaratan yang diminta yaitu pengaruh keragaman keliling pohon berpengaruh terhadap keragaman volume pohon. Ukuran korelasi dinyatakan (Lukito, 2010) sebagai berikut:

c. 0,20 s.d $<0,40$ menunjukkan adanya hubungan yang rendah.

sebesar 5\% memiliki arti bahwa tingkat kesalahan yang diperbolehkan adalah 5\%. Apabila pada uji $\mathrm{F}$ seluruh model memiliki nilai 
F hitung lebih kecil daripada F tabel, maka perlu dilakukannya uji bedanyata atau chi-square.

Nilai SA dan SR dari hasil uji validasi pada semua model persamaan memiliki nilai SA terletak diantara $-93,96$ hingga 16,19 sementara nilai SR pada semua model persamaan yaitu $0,16 \%$ hingga $12,23 \%$. Menurut pernyataan Farida (2016), SA bernilai antara -1 sampai +1 sehingga memenuhi persamaan yang baik dan nilai SR kurang dari 10\%. Dilihat dari Tabel 6

Sementara nilai RMSE pada model persamaan memiliki nilai sebesar $1,03 \%$ hingga 32,97\%. Nilai RMSE menunjukkan ketepatan dari model pendugaan (Freund et al., 2010; Sumadi \& Siahaan, 2010), semakin baik suatu model pendugaan volume adalah yang memiliki Pengujian validasi yang terakir adalah dengan chi-square. Pengujian ini digunakan untuk menguji adakah perbedaan volume dugaan dengan volume aktualnya. Berdasarkan Tabel 6 dapat dilihat bahwa nilai chi-tabel sebesar 27,58 dan hasil perhitungan chi-square pada seluruh model persamaan kecuali model persamaan logaritmik memiliki nilai chi-square kurang dari nilai chi tabelnya. Karena nilai chisquare kurang dari chi-tabel $\left(x^{2}<x^{2}\right.$ tabel $)$ maka H0 diterima yang memiliki arti

Model terbaik masing-masing bentuk persamaan dipilih berdasarkan peringkat dari hasil beberapa kriteria dalam penyusunan tarif dapat dilihat bahwa nilai SA tidak sesuai dengan aturan yang seharusnya karena tidak berada pada -1 hingga +1. Maka penggunaan seluruh persamaan akan menghasilkan bias pada pengamatan tertentu. Namun untuk nilai SR semua model persamaan memiliki nilai dibawah $10 \%$ kecuali model eksponensial. Nilai SR ini memiliki kegunaan untuk mengetahui seberapa jauh nilai data yang menyimpang dari nilai ratarata (Marlia et al, 1999).

nilai RMSE terendah (Tiryana et al., 2011). Model persamaan linear memiliki nilai RMSE terendah yakni sebesar 1,03\%. Artinya variasi volume yang dihasilkan dari model persamaan ini akan mendekati aslinya.

berdasarkan nilai chi-square, nilai volume dugaan tidak berbeda nyata dengan volume aktualnya atau dapat dikatakan terdapat kecocokan antara hasil volume persamaan regresi dengan hasil volume aktual untuk model persamaan linear,kuadratik,power,dan eksponensial. Sedangkan padamodel persamaaan power memiliki nilai chi-square terendah sehingga hasil volume dugaan model ini akan mendekati volume aktual dibandingkan dengan model-model lainnya.

volume. Modelterbaik adalah model dengan skor terendah (Kuswandi,2016). Hasil pemeringkatan atau skoring dapat dilihat pada Tabel 6. 
Tabel 6. Hasil Skoring Seluruh Model Persamaan Penduga Volume Pohon

\begin{tabular}{lcccccccccr}
\hline Model & $\mathrm{R}^{2}$ & $\mathrm{Se}$ & $\mathrm{F}$ & $\mathrm{SA}$ & $\mathrm{SR}$ & $x^{2}$ & Bias & RMSE & Skor $\begin{array}{c}\text { Per- } \\
\text { ingkat }\end{array}$ \\
& & & & & & & & & & \\
\hline Logaritmik & 5 & 3 & 5 & 4 & 3 & 5 & 4 & 5 & 31 & 5 \\
\hline Kuadratik & 4 & 1 & 3 & 3 & 2 & 3 & 5 & 3 & 24 & 3 \\
\hline Power & 1 & 4 & 1 & 1 & 1 & 1 & 2 & 2 & 13 & 1 \\
\hline Eksponensial & 2 & 5 & 4 & 2 & 4 & 2 & 3 & 4 & 26 & 4 \\
\hline Linear & 3 & 2 & 2 & 5 & 4 & 4 & 1 & 1 & 22 & 2 \\
\hline
\end{tabular}

Berdasarkan hasil pemeringkatan pada seluruh model persamaan penduga volume pohon jenis Jati menunjukkan bahwa model linear memiliki skor paling rendah diantara model lainnya. Sehingga tarif volume lokal jenis Jati dapat disusun dengan menggunakan persamaan regresi model power yaitu $\mathrm{V}=$

\section{KESIMPULAN}

Model pendugaan volume pohon yang paling baik untuk menyusun tabel volume jenis Jati (Tectona grandis L.f) di Hutan Kemasyarakatan Sedyo Rukun, RPH Menggoran, BDH Paliyan, Desa Banyusoco, Kecamatan Playen, Kabupaten Gunung Kidul,

\section{DAFTAR PUSTAKA}

Amri Riady. 2011. Penyusunan dan Validasi Persamaan Tabel Volume Lokal Pohon Meranti di Areal PT. Intracawood Manufacturing, Kalimantan Timur.Bogor: Institut Pertanian Bogor.

Bustomi, S., Harbagung, D. Wahyono dan I.B.P. Parthama 1998. Petunjuk TeknisTata Cara Penyusunan Tabel Volume Pohon. Badan Penelitian dan Pengembangan Kehutanan. Pusat Penelitian dan Pengembangan.
$0,016 \mathrm{k}^{2,393}$ dengan nilai $\mathrm{R}^{2}$ 0,865; SA 0,39;

SR $0,16 \%$;Bias 1,76 \%; RMSE 2,68\% dan chi-square 3,03. Perhitungan estimasi volume pohon diperlukan untuk menghitung volume yang dapat dijual, sehingga perkiraan volume diperlukan untuk menentukan ukuran dan jumlah pohon yang harus ditebang (Heigliman and Bratkovich, 2009).

adalah model persamaan. power yaitu $\mathrm{V}=$ $0,016 \mathrm{k}^{2,393}$ dipilih sebagai model terbaik untuk menyusun tarif volume lokal jenis Jati (Tectona grandis L.f). Tarif Volume Lokal Jenis Jati pada areal HKm Sedyo Rukun dapat digunakan dengan menggunakan persamaan $\mathrm{V}=0,016 \mathrm{k}^{2,393}$.

Cahyono, T. 2006. Uji Normalitas. PDF. Diakses pada tanggal 11 Maret 2020 www.scribd.com/ doc/23910549/UJINORMALITAS.

Dahlan, M.S. 2009. Statistik untuk Kedokteran dan Kesehatan, Edisi 4 (Deskriptif,Bivariat dan Multivariat, dilengkapi Aplikasi dengan Menggunakan SPSS). Jakarta: Salemba Medika.

Farida Herry S dan Abduracman. 2016. Analisis Penyusunan Model Pendugaan Volume Pohon 3 Jenis Shorea di Tarakan, 
Kalimantan Utara. Jurnal Penelitian Ekosistem Dipterokarpa Vol 2 No 1 Hal 29-40.

Freddy J.H dan Relawan. K. 2019. Model Penduga Volume Pohon Kelompk Jenis Komersial Pada Areal IUPHHK PT.Tunas Timber Lestari Di Kabupaten Boven Digui, Papua. Jurnal WASIAN Vol 6 No.1.

Freund, R. J., Wilson, W.J., \& Mohr, D.J. (2010). Statistical Methods (Edisi ke- 3). Canada: Academic Press.

Heigliman, R.B. dan Bratkovich, S. M. (2002). Measuring Standing Trees- Determining Diameter, Merchantable Height, and Volume. Ohio State University Fact Sheet School of Natural Resources.

Kuswandi,R. (2016). Model penduga volume pohon kelompok jenis komersial pada wilayah Kabupaten Sarmi, Papua. Jurnal Wasian, 3(2), 91-96.

Lukito, Martin 2010. Inventarisasi Hutan Tanaman Kayu Putih Dalam menghasilkan Biomasassa dan Karbon Hutan. Tesis Fakultas UGM. Tidak Dipublikasikan.

Marlia, R., Sutarahardja, Prihanto. 1999. Studi Penyusunan Volume Lokal Jenis- jenis Komersial Ekspor di Hutan Mangrove HPH PT. Bina Lestari,Riau Jurnal Manajemen Hutan Tropika Vol.V No.2 23-24.

Prodan, M. 1965. Forest Biometric. Perganon, Oxford-London.

Siagian, K. (2011). Tabel Volume Pohon Agathis loranthifolia di Hutan Pendidikan Gunung Walat Kabupaten Sukabumi Provinsi Jawa Barat. Skripsi tidak diterbitkan, Institut Pertanian Bogor, Bogor.

Simon H. 2007. Metode Inventore Hutan.Yogyakarta (ID): Pustaka Pelajar.
Sugiyono. 2011. Statistika untuk Penelitian. Bandung (ID): Alfabeta.

Suharlan, Boestami AS, dan Sumarna K. 1976. Tabel Volume Lokal Pinus merkusii Jungh et de Vriese. Bogor: Lembaga Penelitian Hutan.

Sumadi, A, \& Siahaan,H. (2010). Model penduga volume pohon kayu bawang (Disoxylum molliscimum Burm F.) di Provinsi Bengkulu. Jurnal Penelitian Hutan Tanaman, 7(5), 227-231.

Tiryana, T., Tatsuhara,S., \& Shiraishi, N. (2011). Empirical models for estimating the stand biomass of teak plantations in Java, Indonesia. Journal of Forest Planning, 16, 177-188.

Wahyu Widiarso. 2012. Uji normalitas. yogjakarta. Fakultas Psikologi UGM.

Wayan Arta. 2017. [Skripsi] Model Penduga Tabel Volume Pohon Meranti Di PT.Inhutani II Sub Unit Malianu Kalimantan Utara. Institut Pertanian Bogor. 